\title{
Biotechnological Inventions and Patent Law: National and International Perspective
}

\author{
Jyoti Rattan
}

\begin{abstract}
In the knowledge society of 21st century, intellectual property rights (IPRs) are real assets and much more valuable and important than are materialistic assets like house, motor car, and so on. Patents are given for inventions which fulfill few important conditions, such as novelty, inventiveness, industrial application, and written description. Significantly, biotechnological invention involves monopoly over life or living beings or living processes, and morally and ethically these are considered to involve tinkering with life or nature. However, today, biotechnological inventions are patentable because of their benefits and utility to the industry. This article is a humble attempt to examine international and national law and judicial decisions relating to patents and biotechnological inventions from a theoretical perspective.
\end{abstract}

Keywords: Intellectual property rights, Nonnatural living beings, Novelty, Patent, World intellectual property organization.

How to cite this article: Rattan J. Biotechnological Inventions and Patent Law: National and International Perspective. J Postgrad Med Edu Res 2016;50(3):132-135.

Source of support: Nil

Conflict of interest: None

\section{INTRODUCTION}

In the knowledge society of the 21st century, intellectual property rights (IPRs) are real assets and much more valuable and important than are materialistic assets like house, motor car, and so forth. Even the United Nations has supported it that "in today's knowledge based society, intellectual property is a tool for promoting wealth creation as well as social, economic and cultural development."1 According to World Intellectual Property Organization (WIPO) definition, IPRs refer to creations of the mind, inventions, literary, artistic work, symbols, names, images, and designs used in commerce. Broadly, IPRs could be divided into two parts: Firstly, relating to industrial property which involves patents, industrial designs, and trademarks having industrial applications;

Senior Assistant Professor

Department of Laws, Panjab University, Chandigarh, India

Corresponding Author: Jyoti Rattan, Senior Assistant Professor, Department of Laws, Panjab University, Chandigarh India, Phone: +911722691000, e-mail: jyotirattan@gmail.com and secondly, relating to copyrights covering literary, dramatic and artistic works, performances, production of phonograms, broadcasting , telecasting photographic, and audiovisual works. ${ }^{2}$

The word "patent" has originated from the Latin word "patere," which means to "lay open," that is, make available for public inspection. Patent is an exclusive right to use or exercise an invention, granted to a person by the State for a limited period in consideration of the disclosure of the invention. It excludes others from doing certain acts in relation to that invention for a specific period of time. Further, like the owner of patent or patentee, assignee and licensee (to whom right(s) are transferred by patentee) could also do some acts and exercise certain rights in relation to such invention.

\section{PATENTING BIOTECHNOLOGICAL INVENTION}

Biotechnology is a study relating to the practical application of living beings in different fields or relating to living organisms in the industrial utilization. Biotechnological invention involves monopoly over life or living beings or living processes, and morally and ethically these are considered to involve tinkering with life or nature. Significantly, patenting life was never considered possible because life is a creation of nature and human beings cannot get exclusive right over it. ${ }^{3}$ However, developments in science and technology, especially in biotechnology, have created nonnatural living beings and the application, utility, and benefits of such nonnatural living beings or nonnatural living processes forced our system to broaden the base of patent law, and hence biotechnological inventions became patentable. Therefore, natural life is a creation of nature and hence nonpatentable, whereas nonnatural life is creation of man which involves the application of human ingenuity or intelligence to natural living beings and hence patentable.

Significantly, eight countries have reviewed their patent laws to provide protections to biotechnological inventions which include both developed and developing countries. Besides the United States (US), members of European organizations and Japan, other countries like Korea and Thailand, have done commendable work of harmonizing their patent laws and practice in respect of biotechnological inventions. ${ }^{4}$ 


\section{Patenting Biotechnological Product: International Perspective}

Regarding biotechnological inventions there can be two types of patents: Patent product and patent process. Regarding biotechnological product, historically, till 1980 no patent was granted on living beings anywhere in the world. In 1948, in Funk Brothers Seed Company vs Kalo Incoculant Company, ${ }^{5}$ the US Supreme Court refused to grant patent on nonnatural seeds. Further, in 1976 the German Supreme Court, in Red Dove case, ${ }^{6}$ also refused to grant patent on nonnatural living beings. For the first time in 1980, in Diamond vs Anandha Chakraburty, ${ }^{7}$ the US Supreme Court granted a patent on microorganism, that is, a nonnatural or genetically modified bacterium which was capable of performing certain nonnatural functions of eating and cleaning up oil spills, and that nonnatural living beings are covered under the phrase "composition of matter" and hence patentable.

Considering this decision of the US Supreme Court, a patent was granted by a European court in Genentech-I/ Polypeptide expression ${ }^{8}$ on plasmid, a microorganism genetically modified to express foreign proteins. The European court held that under the European Patent Convention of 1977, naturally produced living being, such as plants, animals, and microorganisms are nonpatentable. However, it excludes the nonnatural living beings which, according to court, are patentable. Subsequently, in the 1990 Harvard/Oncomouse case, ${ }^{9}$ patent was granted by the US Patent office on Oncomouse, a nonnatural animal, which is genetically modified to become susceptible to cancer and so was useful in cancer research. Considering this decision, US patent office also granted patent on Oncomouse.

These decisions of US and European courts encouraged the granting of patent to nonnatural plants. For the first time in Exparte Hibber, ${ }^{10}$ patent was granted on nonnatural mutant of maize plant where the inventor incorporated certain properties and the features in the maize plant, which did not exist in natural maize plant. Further, in many cases patent was granted on nonnatural plants, i.e., in Ciba-Geigy/propagating material ${ }^{11}$ on seeds of a genetically modified plant, in Lubrizol/Hybrid plants ${ }^{12}$ on hybrid plants, and in plant genetic system ${ }^{13}$ on genetically modified plants and plant cells.

This trend of granting patent to nonnatural living beings also encouraged granting patent to human genetic material. In John Moore case, patent was granted on the cell lines of human beings which were useful in producing cancer-fighting proteins. Subsequently, in re Bell ${ }^{14}$ and in re Deuel, ${ }^{15}$ patents were granted on human genetic material, such as deoxyribonucleic acid (DNA) and ribonucleic acid (RNA).
In Howard Florey/Relaxin, ${ }^{16}$ patent granted by European Patent Office for the genetic engineering of DNA from a pregnant woman's body to produce a human $\mathrm{H} 2$ relaxin was upheld by the court. Further in Novartis case, ${ }^{17}$ it was made clear that DNA, RNA, and human cells could be patented. However, in present scenario, important question is whether a human being or a human clone though genetically engineered or nonnaturally produced can be patented? In 1994, in the case of Pioneer Hi-bred International vs Holden Foundation Seeds Inc., ${ }^{18}$ the US Supreme Court clearly laid down that human cloning and human being is not patentable.

After this decision of US court, the European Union adopted the European Union Directive on Legal Protection of Biotechnological Inventions in 1998 which clearly prohibited nonnatural human being and human cloning from patenting. Subsequently, the United States enacted the US Human Cloning Prohibition Act 2003 to prohibit human cloning and human being from cloning.

In June 13, 2013, in Association for Molecular Pathology et al vs Myriad Genetics Inc. et al, ${ }^{19}$ Justice Clarence Thomas of the US Supreme Court held that "genes and the information they encode are not patent-eligible... simply because they have been isolated from the surrounding genetic material." In this case, respondent Myriad Genetics Inc. (Myriad) obtained several patents after discovering the precise location and sequence of the "breast cancer gene 1" (BRCA1) and "breast cancer 2, early onset" genes (BRCA2). ${ }^{20}$ Petitioners filed suit to declare Myriad's patents invalid under inventions patentable. ${ }^{21}$ The District Court granted summary judgment to petitioners, concluding that Myriad's claims were invalid because they covered products of nature. The Federal Circuit initially reversed, but on remand in light of Mayo Collaborative Services vs Prometheus Laboratories ${ }^{22}$ the Circuit found both isolated DNA and composite DNA are not patentable. Ultimately, the US Supreme Court held that natural genes are nonpatentable.

Significantly, the US Patent and Trademark Office (USPTO) gave new Guidelines for Determining Subject Matter Eligibility of Claims Reciting or Involving Laws of Nature, Natural Phenomena, and Natural Products on March 4, 2014. ${ }^{23}$ These guidelines have raised controversy for patenting Ebola virus. Initially, the US Centers for Disease Control and Prevention (CDC) got patent in 2010 for a strain of the Ebola virus (EboBun), ${ }^{24}$ i.e., the patent is for a vaccine or the antibodies generated against the virus. However, it is different from the Ebola Zaire (EBOV) virus, which is the cause of the 2014 outbreak..$^{25}$ The US government's latest Ebola patent application has been rejected by the USPTO based on different problems. That means research on Ebola going on around the world will continue. ${ }^{26}$ 


\section{Patenting Biotechnological Process: International Perspective}

Nonnatural or genetically modified living beings are the results of nonnatural and genetically modified biological processes. Adding human ingenuity to natural process makes it nonnatural. Therefore, for patenting biotechnological process, inventor must prove to the satisfaction of the patent officer that biotechnological process is nonnatural. In 1986, in the case of Hybertech Inc. vs Monoclonal Antibodies Inc., ${ }^{27}$ patent was granted for the process of utilizing proteins produced inside a body to fight against diseases, and the court held that it is an unnatural process as protein produced inside a body was used to fight against disease on human prescription. Subsequently, in many other cases the court upheld granting of process patent; for example, in re Wands ${ }^{28}$ on a process of detecting viruses causing hepatitis B diseases, in re Farrell ${ }^{29}$ on a process to produce foreign proteins in bacteria in a nonnatural way, and in 1996 a European court in Chiron vs Murex Diagnostic ${ }^{30}$ on a process of producing proteins through in vitro propagation of hepatitis $C$ virus in a nonnatural and biotechnological way.

\section{Patenting Biotechnological Invention: Indian Perspective}

Section 3 of the Indian Patent Act 1970 mentions nonpatentable inventions, such as an invention which is frivolous or which claims anything obviously contrary to well-established natural laws, intended use or exploitation of which would be contrary to public order or morality or which causes serious prejudice to human, animal, or plant life or health or to the environment. ${ }^{31}$ This means that only those biotechnological inventions are patentable in India which are useful to society, hence any invention which is harmful to law of nature or human, animal, or plant life or health or to the environment is nonpatentable in India. In Dimminaco AG vs Controller of Patents and Design, ${ }^{32}$ the Kolkata High Court held that the process of preparing a commodity which contains a living substance is also covered under the purview of manufacture. Accordingly, process patent was issued to the applicant by the patent office.

It is important to mention here that there are not yet much judicial decisions in India about patenting of biotechnological inventions.

\section{CONCLUSION AND SUGGESTIONS}

After critical analysis, it is concluded that patent is an exclusive right granted by the state for an invention, which is a product or a process. However, such invention must involve inventiveness and must be useful to society.
In other words, it must either provide a new way of doing something or offers a new technical solution to a problem. However, to get a patent, technical information about the invention must be disclosed to the public in a patent application. On the whole, patents are incentives to invent and innovate things which are new and useful..$^{33}$

Undoubtedly, the main advantage of patent is that it is an exclusive right provided to a patent holder, but it has certain drawbacks also, such as for 20 years no one except the patentee can use any part of the patent product or process. That means in patent process the use of one step by someone else may amount to infringement of patent. Another drawback of patent is price inflation; i.e., as patents are an exclusive right that creates a temporary monopoly, the patent holder can set a market price higher than the competitive price.

Further, there are other drawbacks: After the expiry of exclusive patent period (20 years), any other entity can freely use the invention without any permission from the patentee; applying for patent can be a very lengthy, timeconsuming process; cost of patent filing may be higher than the actual financial gains; and patentee must defend its patent if need be and lastly, taking action against infringement is costly. ${ }^{34}$ Despite these drawbacks, patent is considered as strong protection to the inventor.

Initially plants, animals, and human beings were kept out of the purview of patent law. However, toward the end of 20th century a new development was seen in patent laws whereby a new trend started under which biotechnological inventions (product and process) could also be patented.

Today, biotechnology is a driving force of modern world, and patent law has reached unprecedented and unforeseen destination as nonnatural lives, or nonnatural living being, and nonnatural processes are patentable. The inventions of biotechnology, which involve addition of human intelligence to the natural processes in producing nonnatural and genetically modified living beings, range from nonnatural microorganisms like bacteria, plasmid, nonnatural plant, nonnatural animal, and nonnatural human genetic material which are undoubtedly patentable in the present scenario. However, in this regard, the decision of the US Supreme Court in 2013 in Association for Molecular Pathology et al vs Myriad Genetics Inc. et $\mathrm{al}^{35}$ is worth mentioning. It held that "genes and the information they encode are not patentable," as these are not nonnatural genetic material. New guidelines issued by the USPTO made Ebola Virus a nonpatentable invention as it is a natural product. Besides, biotechnological process could also be patented.

Today, due to population explosion and other reasons, there is a need of having food and health services at cheaper rates. The solution has been provided by 
developments in biotechnology. Now biotechnology has become a challenging technique for established industries. Crops may be genetically manipulated to improve their commercial quality and to make them resistant to insects, diseases, or herbicides. Similarly, animal stock can be improved. Also human genetic material could be modified to grow organs for transplantation into humans, to cope with the shortage of natural product. Similarly, stem cell research could do commendable work in the treatment of various diseases, such as osteoporoses, heart attack, diabetes, hepatitis, burn, and degeneration conditions, such as muscular dystrophy, Alzheimer, or Parkinson's disease. Further, embryonic stem cell (eSC) research could provide life to a number of couples. Regarding human cloning and human being, certain countries like the United States and European countries have made it legally nonpatentable. Position is also same under section 3 of Indian Patent Act 1970. Therefore, careful use of patent law holds a significant promise in several areas for the entire humankind.

\section{REFERENCES}

1. Basic Facts about the United Nations, United Nations Publication (2014), p. 152.

2. The United Nations Today, the United Nations Department of Public Information, New York (2008), p. 174.

3. N.S. Sreenivasulu, Intellectual Property Rights, Regal Publication New Delhi, (2007), p. 53.

4. Pal Prankrishan, Intellectual Property Rights in India General Issues and Implications, Regal Publication New Delhi, (2008), p. 71.

5. 33 US 127 (1949).

6. Available from: http://www.fountainmagazine.com/Issue/ detail/PATENTING-PLANTS-AND-ANIMALS $\mathrm{p}$ [accessed on January 25, 2015].

7. (1980) US 404.

8. (T292 /85) [1989] E.P.O.R. 1, EPO (Technical Bd App).
9. Harvard/Oncomouse (1990) O.J. EPO 476.

10. 227 USPQ 443.

11. 1984 O.J. EPO 112.

12. 1990 O.J. EPO 59.

13. (1995) O.J. EPO 545.

14. 991F. 2d 781 (Fed. Cir. 1993).

15. 51F 3di 552 (Fed. Cir. 1995).

16. [1995] P.P.O.R. 541 at 551

17. 98/44 (1998) O.J. L312/13.

18. 35F, 3d 1226.3, USPQ 2d 1385 (8th CIR. 1994).

19. 689 F. $3 d 1303$.

20. Mutations of these genes can dramatically increase the risk of breast and ovarian cancers. If valid, Myriad's patents would give it the exclusive right to isolate an individual's BRCA1 and BRCA2 genes and would give Myriad the exclusive right to synthetically create BRCA cDNA.

21. 35 U. S. C. $\$ 101$.

22. 132 S.Ct. 1289.

23. Available from: http://www.uspto.gov/patents/law/exam/ myriad-mayo_guidance.pdf [accessed on January 25, 2015].

24. Patent No. CA2741523A1 granted in 2010 for EboBun.

25. This resulted in over 4,500 deaths in sub-Saharan Africa and new cases were identified in two developed countries that are struggling and faltering in their handling of the epidemic, the 2014 Ebola Virus Disease (EVD). Available from: http:/ / mchandaids.org/?p=2373\#sthash.401es3SC.dpuf [accessed on January 25, 2015].

26. Available from: http://www.ibtimes.com/us-governmentwants-patent-ebola-virus-heres-why- thats-good-thing-1719681 [accessed on January 25, 2015].

27. 802 F. 2d 1367 (Fed. Cir. 1986).

28. 858 F.2d 731 (Fed. Cir. 1986).

29. 853 F.2d 894 (Fed. Cir. 1988).

30. [1996] F.S.R 153.

31. Management of Intellectual Property Rights in India. Available from: http:/ / www.pfc.org.in/workshop/workshop.pdf [accessed on December 2, 2014].

32. IPLR 2002 Jul 255 (Cal).

33. Supra note 15, p. 134.

34. Available from: http://www.entrepreneur.com/article/80088.

35. 689 F. $3 d 1303$ 